ORIGINAL ARTICLE

PRACA ORYGINALNA

\title{
DETERMINING THE FREQUENCY OF FUNCTIONAL DISORDERS OF THE TMJ IN PATIENTS WITH MANDIBLE FRACTURES DEPENDING ON THE LOCATION
}

DOI: 10.36740/WLek202002107

\author{
Olga L. Skrypa', Yurii L. Bandrivsky² \\ "HSEE "BUKOVINIAN STATE MEDICAL UNIVERSITY", CHERNIVTSI, UKRAINE \\ 2. HORBACHEVSKY TERNOPIL STATE MEDICAL UNIVERSITY, TERNOPIL, UKRAINE
}

\begin{abstract}
The aim: To investigate the frequency of functional TMJ disorders in patients with fractures of the mandible.

Materials and methods: To achieve this goal, 111 patients hospitalized in the department of surgical dentistry of the Chernivtsi Regional Clinical Hospital were examined for traumatic fractures of the mandible with functional disorders of the TMJ (occlusive, muscular, articular disorders). The examination of patients with functional disorders was based on Express - the conclusion of the Hamburg Protocol:

1. pain in palpation of joints;

2. pain in palpation of chewing muscles;

3. presence of noises in the joints;

4. violation of the opening trajectory;

5. the opening of the mouth is limited;

6. eccentric occlusion, premature contacts.

Statistical processing of research results was carried out using commonly used methods of variation statistics.

Results: We found that on average, mandibule fractures showed the highest number of single-function occlusion's (18.92\%) and articular disorders (21.62\%) and multifunctional occlusal-articular disorders (20.72\%), with the smallest the frequency of one-function muscle`s disorders (4.50\%). Multifunctional TMJ disorders «occlusal + muscle» and «muscular-articular» in this contingent of patients were determined, on average, at the same percentages (10.81\%). Attention was drawn to the fact that «muscular + articular» dysfunction of the TMJ was diagnosed more frequently with the immobilization of the fragment with the help of osteosynthesis $(18,18 \pm 4,54 \%)$ and with the combined method $(15,39 \pm 3,84 \%)$ than when both jaws are splinted, $\mathrm{p}<0,05$.

Conclusions: It was established that in patients with fractures of the jaws of different localization single-functional articular disorders (21.62\% of the subjects) and multifunctional «occlusion-articular» disorders ( $20.72 \%$ of the examined) predominated. In this case, the frequency of TMJ dysfunction, to a large extent, depended on the nature of the displacement and the way of immobilization of the fragments of the mandible.
\end{abstract}

KEY WORDS: fracture of the mandible, TMJ, occlusive disorders, muscle disorders, joint disorder

Wiad Lek. 2020;73(2):245-249

\section{INTRODUCTION}

Prevention, diagnosis and treatment of damages of the maxillofacial area is one of the most urgent modern medical and social problems, the significance of which is determined by the constant increase in the frequency of maxillofacial injuries, which averages from 6,0 to $16,4 \%$ of all injuries of peacetime $[1,2]$. Prevalent these injuries in most cases in men, which is expressed in relation to women in the proportion of 7: 1-9:1, and their peak predominantly occurs in the second to fourth decades of life $[3,4]$. However, in recent years there has been a tendency to increase the number of victims is precisely at the age of 25 years. [5]. Among injuries of the maxillofacial area fractures of the mandible are most common and occur in $67.3-87.1 \%$ of cases [6, 7]. From 65,8 to $82 \%$ of the fractures of the mandible are localized within the dentition, and therefore are open $[8,9,10]$.
The main attention in domestic and foreign literature was directed at the study of internal disorders in the TMJ, due to fractures of the of the processus frontalis $[11,12]$. The question of treatment of musculo-joint disorders caused by fractures of the mandible of other localizations, as a rule, was not addressed in a timely manner and, accordingly, not resolved [13, 14].

This explains the relevance of the study. Lack of purposeful early complex treatment of musculo-joint disorders caused by fractures of the mandible of different localization led to an inappropriate diagnosis and underestimation by all dental specialists (surgeons, therapists, orthopedists, orthodontists, etc.).

Numerous publications on muscular and articular dysfunction of the TMJ are devoted to the etiology, pathogenesis, morphology, clinic, diagnosis and treatment of this 
multifactorial disease $[15,16]$. In rare studies reflected the remote consequences of fractures of the mandible as a possible cause of muscular and articular dysfunction of the TMJ [17].

Indicators of the incidence of TMJ dysfunction remain high and, according to various authors, range from 27.5 to $89 \%$ of the adult population surveyed [18]. However, the dysfunction of the TMJ is considered only as a type of myofascial pain in the person's face, and is not isolated in a separate nosological form.

There is an unsolved question about adequate treatment not only fractures of the mandible, but also muscular and articular dysfunction of the TMJ in all stages of medical rehabilitation [19].

Therefore, today the problem is actual of comprehensive study of pathogenetic mechanisms of muscular articular dysfunction of the TMJ, improving the quality of its early diagnosis, as well as the implementation of differentiated targeted correction of the revealed violations and prevention of possible complications in patients with muscular and articular dysfunction of the TMJ with fractures lower jaw of different localization.

\section{THE AIM}

To investigate the frequency of functional TMJ disorders in patients with fractures of the mandible.

\section{MATERIALS AND METHODS}

To achieve this goal, 111 patients hospitalized in the department of surgical dentistry of the Chernivtsi Regional Clinical Hospital were examined for traumatic fractures of the mandible with functional disorders of the TMJ (occlusive, muscular, articular disorders). The examination of patients with functional disorders was based on Express - the conclusion of the Hamburg Protocol:

1 - pain in palpation of joints;

2 - pain in palpation of chewing muscles;

3 - presence of noises in the joints;

4 - violation of the opening trajectory;

5 - the opening of the mouth is limited;

6 - eccentric occlusion, premature contacts.

Statistical processing of research results was carried out using commonly used methods of variation statistics.

\section{RESULTS AND DISCUSSION}

One of the stages of the analytical study of TMJ in patients with fractures of the mandible of different localization was the determination of the frequency of its functional disorders (Table 1).

As a result of our researches, $45.05 \%$ of single-functional disorders and $54.95 \%$ of multifunctional disorders were diagnosed in 111 patients with fractures of the mandible of different localization. The analysis of the frequency of single-function disorders showed their absence in persons with a coronoid process fracture. At the same time, oclusive disorders of the TMJ were most commonly encountered in fractures of the mandible $-4.55 \pm 1.11 \%$ of the examined, $\mathrm{p}<0.01$, whereas in persons with medial, lateral fractures $(25.0 \pm 6.29 \%$ and $25,93 \pm 6.48 \%$, respectively, $\mathrm{p}>0.05)$ and with fractures in the region of the mandible angle $(22.86 \pm 5.72 \%, \mathrm{p}, \mathrm{p} 1>0.05)$, the incidence of this disorder was the same.

Muscular TMJ disorders were not diagnosed in patients with a medialle cervical fractures in the coronoid process of the mandible. At the same time, the percentage of persons with this type of disorder with lateral fractures and its location in the area of the mandible angle was the same and amounted to $7.41 \pm 1.85 \%$ and $8.57 \pm 2.14 \%$ respectively, p1>0.05. Single-functional articular disorders TMJ not objectified in persons with fractures of the coronoid process of the mandible. At the same time, this type of TMJ disorder was diagnosed, on average, 2.0 times more in persons with fractures in the cervical part of the mandible than in patients with medial, lateral and fractures in the regionangle of the mandible, p, p1, p2>0.05.

In the analysis of multifunctional TMJ disorders in the background of jaw fractures it was found that "occlusive + muscular disorders" were not diagnosed with fractures in the coronoid process of the mandible. At the same time, the highest frequency of this type of disorder was determined in patients with median fractures $(20,0 \pm 5,00 \%)$ and with fractures of the coronoid process of the mandible $-14,29$ $\pm 3,57 \%, \mathrm{p}>0,05$.

Frequency of occlusal-articular disorders in patients with jaw fractures ranged from $28,56 \pm 7,14 \%$ in persons with coronoid process fractures, $\mathrm{p}, \mathrm{p} 1, \mathrm{p} 2, \mathrm{p} 3>0.05$ to $14.81 \pm 3.70 \%$ of patients with lateral fractures of the mandible, $p>0,05$.

It should be noted that "occlusal + muscular + articular" disorders of the TMJ were more common in persons with fractures coronoid process of mandibule $-42.86 \pm 10.72 \%$ $\mathrm{p}, \mathrm{p} 2, \mathrm{p} 3<0.05, \mathrm{p} 1<0,01$, with a minimum frequency of this type of disorder in patients with lateral fractures -3.70 $\pm 0.93 \%, p<0,05$. For persons with medialle fractures and with its localization in the region of the angle mandible, the incidence of this type of TMJ disorder was practically the same - it was $10,0 \pm 2,50 \%$ and $11,43 \pm 2,86 \%$ of the subjects, $\mathrm{p}>0,05$. The frequency this type of TMJ disorder in persons with fractures in the cervical area of the mandibule was slightly higher and equaled $18.18 \pm 4.45 \%$ of subjects, p, p2>0.05, p1<0.01.

Multifunctional disorders such as "muscle and articular" were not diagnosed in patients with median fractures, and their prevalence varied from the minimum values for fractures of the angle mandible $-8.57 \pm 2.14 \%$ of subjects, $p$, $\mathrm{p} 1>0.05$, up to maximum data $-18,52 \pm 4,63 \%$ in subjects with lateral fractures of the mandible.

Thus, it was found that, on average, at the mandibule fractures, single- functional disordersof TMJ was: occlusion `s (18.92\%), articular disorders (21.62\%) and multifunctional occlusal-articular disorders (20.72\%) were present in the largest number. At the lowest frequency of single-function muscles disorders (4.50\%). Multifunctional TMJ disorders "occlusal + muscle" and "muscular-articular" in this 
Table 1. Distribution of patients with fractures of mandibule with temporomandibular disorders.

\begin{tabular}{|c|c|c|c|c|c|c|c|c|}
\hline \multirow{3}{*}{$\begin{array}{l}\text { Localization } \\
\text { fractures } \\
\text { of mandible }\end{array}$} & \multirow{3}{*}{$\begin{array}{l}\text { Number of } \\
\text { patients } \\
\text { with TMJ } \\
\text { dysfunction }\end{array}$} & \multicolumn{3}{|c|}{ Single-functional disorders } & \multicolumn{4}{|c|}{ Multifunctional disorders } \\
\hline & & $\begin{array}{l}\text { Occlusion } \\
\text { disorders }\end{array}$ & $\begin{array}{l}\text { Muscular } \\
\text { disorders }\end{array}$ & $\begin{array}{l}\text { Articular } \\
\text { disorders }\end{array}$ & $\begin{array}{l}\text { Occlusion } \\
\text { + muscular } \\
\text { disorders }\end{array}$ & $\begin{array}{l}\text { Occlusion } \\
\text { + articular } \\
\text { disorders }\end{array}$ & $\begin{array}{l}\text { Occlusion } \\
\text { + muscle } \\
\text { + articular } \\
\text { disorders }\end{array}$ & $\begin{array}{l}\text { Muscular } \\
+ \text { articular } \\
\text { disorders }\end{array}$ \\
\hline & & Abs. / \% & Abs. / \% & Abs. / \% & Abs. / \% & Abs. / \% & Abs. $/ \%$ & Abs. / \% \\
\hline Medial fractures & 20 & $\begin{array}{c}5 / \\
25,0+6,25 \\
\end{array}$ & 0 & $\begin{array}{c}4 / \\
20,0+5,0\end{array}$ & $\begin{array}{c}4 / \\
20,0+5,0\end{array}$ & $\begin{array}{c}5 / \\
25,0+6,25 \\
\end{array}$ & $\begin{array}{c}2 / \\
10,0+2,50 \\
\end{array}$ & 0 \\
\hline Lateral fractures & 27 & $\begin{array}{c}7 / \\
25,93+6,48\end{array}$ & $\begin{array}{c}2 / \\
7,41+1,85\end{array}$ & $\begin{array}{c}5 / \\
18,52+4,63\end{array}$ & $\begin{array}{c}3 / \\
11,11+2,78\end{array}$ & $\begin{array}{c}4 / \\
14,81+3,70\end{array}$ & $\begin{array}{c}1 / \\
3,70+0,93^{\circ \circ}\end{array}$ & $\begin{array}{c}5 / \\
18,52+4,63\end{array}$ \\
\hline $\begin{array}{c}\text { In the area of } \\
\text { the angle of the } \\
\text { mandible }\end{array}$ & 35 & $\begin{array}{c}8 / \\
22,86+5,72\end{array}$ & $\begin{array}{c}3 / \\
8,57+2,14\end{array}$ & $\begin{array}{c}6 / \\
17,14+2,86\end{array}$ & $\begin{array}{c}4 / \\
11,43+2,86\end{array}$ & $\begin{array}{c}7 / \\
20,0+5,0\end{array}$ & $\begin{array}{c}4 / \\
43,0+2,86^{* * *}\end{array}$ & $\begin{array}{c}3 / \\
8,57+2,14\end{array}$ \\
\hline $\begin{array}{c}\text { Cervical } \\
\text { (at the site of } \\
\text { the articulation } \\
\text { process) }\end{array}$ & 22 & $\begin{array}{c}1 / \\
4,55+1,11\end{array}$ & 0 & $\begin{array}{c}9 / \\
40,9+10,48\end{array}$ & 0 & $\begin{array}{c}5 / \\
22,73+5,68\end{array}$ & $\begin{array}{c}4 / \\
18,18+4,45^{*}\end{array}$ & $\begin{array}{c}3 / \\
13,64+3,41\end{array}$ \\
\hline $\begin{array}{l}\text { Fractures of the } \\
\text { coronoid process } \\
\text { of the mandible }\end{array}$ & 7 & 0 & 0 & 0 & $\begin{array}{c}1 / \\
14,29+3,57\end{array}$ & $\begin{array}{c}2 / \\
28,56+7,14\end{array}$ & $\begin{array}{c}3 / \\
42,86+10,72 \\
\circ *, \mathbf{m}, \Delta\end{array}$ & $\begin{array}{c}1 / \\
14,29+3,51\end{array}$ \\
\hline Total & $\begin{array}{c}111 / \\
100\end{array}$ & $\begin{array}{c}21 / \\
18,92+3,72\end{array}$ & $\begin{array}{c}5 / \\
4,50+1,96\end{array}$ & $\begin{array}{c}24 / \\
21,62+3,91\end{array}$ & $\begin{array}{c}12 / \\
10,81+2,95\end{array}$ & $\begin{array}{c}23 / \\
20,72+3,85\end{array}$ & $\begin{array}{c}14 / \\
12,62+3,15\end{array}$ & $\begin{array}{c}12 / \\
10,81+2,95\end{array}$ \\
\hline
\end{tabular}

Notes:

1. ${ }^{\circ}<<0,01 ;{ }^{\circ 0} p<0,05-$ a reliable difference in values for data in patients with median fractures of the mandible.

2. ${ }^{*} \mathrm{p} 1<0,01 ;{ }^{* *} \mathrm{p} 1<0,05-$ a reliable difference in values for data for lateral fractures of the mandible.

3. $-p 2<0,05-$ a reliable difference regarding the data values in patients with fractures of the mandibular angle.

$4 . \Delta \mathrm{p} 3<0,05-$ a reliable difference in values for data in patients with cervical fractures in the coronoid process of the mandible.

contingent of patients were determined on average on the same percentage percent (10.81\%).

The generalized processing of data in Table 2 allowed summing up the frequency of single- and multi-functional TMJ disorders, depending on the nature and method of immobilization of the fractures of the mandible in patients of the study group.

We found that oclusive disorders of TMJ in patients with jaw fractures were found to be 4.9 times more often with a slight displacement than with significant displacement of the fractures of the mandible $(29.51 \pm 5.84 \%$ vs. $6.0 \pm$ $1.05 \%, \mathrm{p}<0.01)$. The single-function articular dysfunction of the TMJ was objectified in individuals of the study group in the same quantities of patients, despite the nature of the displacement of the fragmentes in fractures of the mandible, $p>0.05$. At the same time, with significant displacement of the fragmentes of the mandible in patients, "occlusal + muscle" and "muscle + articular" disorders of the TMJ (2.4 and 1.7 times, respectively) were diagnosed than in patients with a slight displacements of fragments of the mandible, $p>0,05$.

The number of patients with traumatic lesions of the mandible in "occlusal + articular" and "occlusal + articular + muscle" disorders of the TMJ was the same for different types of displacement of the fractures, and the obtained data did not differ statistically significans, $\mathrm{p}>0.05$.

At the same time, single-functional occlusive disorders of the TMJ were found to be more common when we used spliting the both jaws than in osteosynthesis $(28,99 \pm$
$4,51 \%$ vs. $9,09 \pm 2,27 \%, \mathrm{p}<0,01)$. Muscular disorders of the TMJ were diagnosed more frequently in patients with fractures of the jaws with osteosynthesis $(9.09 \pm 2.27 \%$, p > $0.05)$ and with combined imobilization of the fragments $(7.69 \pm 1.92 \%, p>0.05)$ of the lower jaw, than with the spliting of the both jaws. More often, single-functional articular disorders of the TMJ were objectified in patients with a the spliting of the both jaws $-22.99 \pm 4.51 \%$ of the subjects, which was 1.3 and 1.5 times higher than that of individuals with osteosynthesis and a combined method of immobilization fragments of the mandibule, $p>0.05$.

It was established that in the combined method of immobilization of the fragments of the mandible 2,5 times more were "occlusal + muscle" disorders of the TMJ, than with both-jaw splinting and osteosynthesis $(23.07 \pm 5.76 \%$ vs. $9.20 \pm 2.94 \%$ and $9.09 \pm 2.27 \%, \mathrm{p}<0.05$, respectively). The "occlusal + articular" dysfunction of the TMJ was characterized by maximum values when we used the both-jaw spliting and combined methods of immobilization of the fractures of the mandible, $p>0.05$, and was on average 2.5 times higher than with osteosynthesis, $p<0.05$. Multifunctional "occlusal + muscular + articular" disorders of TMJ with the maximum frequency were determined at immobilization of the mandible with osteosynthesis - $27.28 \pm$ $6.82 \%$ of the subjects, $\mathrm{p}<0.05$. At the same time, this type of disorder was objectified in $10,34 \pm 3,24 \%$ patients with both-jaws spliting, and also $15,39 \pm 3,84 \%$ at individuals which used using a combined method of immobilization of the fragments of the mandible. 
Table 2. Frequency of functional disorders of TMJ depending on the nature and method of immobilization of fractures of the mandible.

\begin{tabular}{|c|c|c|c|c|c|c|c|}
\hline \multirow{3}{*}{$\begin{array}{c}\text { Dislocation fragments of } \\
\text { the mandibule }\end{array}$} & \multicolumn{3}{|c|}{ Single-functional disorders } & \multicolumn{4}{|c|}{ Multifunctional disorders } \\
\hline & $\begin{array}{l}\text { Occlusion } \\
(n=21)\end{array}$ & $\begin{array}{l}\text { Muscular } \\
\quad(n=5)\end{array}$ & $\begin{array}{l}\text { Articular } \\
(n=24)\end{array}$ & $\begin{array}{c}\text { Occlusion + } \\
\text { muscle } \\
(n=12)\end{array}$ & $\begin{array}{l}\text { Occlusion + } \\
\text { Articular } \\
(n=33)\end{array}$ & $\begin{array}{l}\text { Occlusal + } \\
\text { muscular } \\
+ \text { articular } \\
(n=14)\end{array}$ & $\begin{array}{c}\text { Muscular + } \\
\text { Articular } \\
(n=12)\end{array}$ \\
\hline & Abs. $/ \%$ & Abs. /\% & Abs. $/ \%$ & Abs. $/ \%$ & Abs. $/ \%$ & Abs. $/ \%$ & Abs. $/ \%$ \\
\hline $\begin{array}{l}\text { Slight displacement } \\
\qquad(\mathrm{n}=61)\end{array}$ & $\begin{array}{c}18 / \\
29,5+5,84\end{array}$ & 0 & $\begin{array}{c}14 / \\
22,95+5,38\end{array}$ & $\begin{array}{c}34 / \\
6,56+3,17\end{array}$ & $\begin{array}{c}12 / \\
19,67+5,09\end{array}$ & $\begin{array}{c}8 / \\
13,11+4,32 \\
\end{array}$ & $\begin{array}{c}5 / \\
8,20+3,51\end{array}$ \\
\hline Significant offset $(n=50)$ & $\begin{array}{c}3 / \\
6,0+1,05^{\circ}\end{array}$ & $\begin{array}{c}5 / \\
10,0+4,24\end{array}$ & $\begin{array}{c}10 / \\
20,0+5,66\end{array}$ & $\begin{array}{c}8 / \\
61,0+5,18\end{array}$ & $\begin{array}{c}11 / \\
22,0+5,86\end{array}$ & $\begin{array}{c}6 / \\
12,0+4,60\end{array}$ & $\begin{array}{c}7 / \\
14,0+4,91\end{array}$ \\
\hline \multicolumn{8}{|c|}{ Method of immobilization of the fragments of the mandible } \\
\hline $\begin{array}{c}\text { Both-jaw } \\
\text { splinting }(n=87)\end{array}$ & $\begin{array}{c}20 / \\
22,99+4,51\end{array}$ & $\begin{array}{c}3 / \\
3,44+0,86\end{array}$ & $\begin{array}{c}20 / \\
22,99+4,51\end{array}$ & $\begin{array}{c}8 / \\
9,20+2,94\end{array}$ & $\begin{array}{c}19 / \\
21,84+4,43\end{array}$ & $\begin{array}{c}9 / \\
10,34+3,24\end{array}$ & $\begin{array}{c}8 / \\
9,20+2,94\end{array}$ \\
\hline Osteosynthesis $(n=11)$ & $\begin{array}{c}1 / \\
9,09+2,27^{\circ 0} \\
\end{array}$ & $\begin{array}{c}1 / \\
9,09+2,27\end{array}$ & $\begin{array}{c}2 / \\
18,18+4,54\end{array}$ & $\begin{array}{c}1 / \\
9,09+2,27\end{array}$ & $\begin{array}{c}1 / \\
9,09+2,27^{\circ \circ}\end{array}$ & $\begin{array}{c}3 / \\
27,28+6,82^{\circ \circ}\end{array}$ & $\begin{array}{c}2 / \\
18,18+4,54^{\circ \circ}\end{array}$ \\
\hline $\begin{array}{l}\text { Combined } \\
(n=13)\end{array}$ & - & $\begin{array}{c}1 / \\
7,69+1,92\end{array}$ & $\begin{array}{c}2 / \\
15,39+3,84\end{array}$ & $\begin{array}{c}3 / \\
23,07+5,76^{\circ 0}\end{array}$ & $\begin{array}{c}3 / \\
23,07+5,76\end{array}$ & $\begin{array}{c}2 / \\
15,39+3,84\end{array}$ & $\begin{array}{c}2 / \\
15,39+3,84^{\circ \circ}\end{array}$ \\
\hline
\end{tabular}

Note:

${ }^{\circ} p<0,01 ;{ }^{\circ} p<0,05$ - a reliable difference regarding the data values in patients with a slight shift of the fragments when we used immobilization of both-jaw.

Attention was drawn to the fact that "muscular + articular" dysfunction of the TMJ was diagnosed more frequently with the immobilization of the fragments with the help of osteosynthesis $(18,18 \pm 4,54 \%)$ and with the combined method $(15,39 \pm 3,84 \%)$ than with the use of both-jaws spliting, $\mathrm{p}<0,05$.

\section{CONCLUSIONS}

It was established that in patients with fractures of the jaws of different localization single-functional articular disorders (21.62\% of the subjects) and multifunctional «occlusion-articular» disorders (20.72\% of the examined) predominated. In this case, the frequency of TMJ dysfunction, to a large extent, depended on the nature of the displacement and the way of immobilization of the fragments of the mandible.

\section{REFERENCES}

1. M. Cabalag, J. Wasiak, N. Andrew et.al. Epidemiology and management of maxillofacial fractures in an Australian trauma centre. J. PlastReconstrAesthetSurg. 2014;67(2):183-189.

2. Bandrivsky Y, Bandrivska 0, Gnid R, Minko L, Shevchuk M. Indicators of markers of bone metabolism in patients with generalized periodontitis depending on blood group. Arch Balk Med Union 2019;54(1):72-77. doi. org/10.31688/ABMU.2019.54.1.10

3. Iryna S. Dankevych-Kharchyshyn et al. Periodontal diseases and atherosclerosis (literature reviewwiad). Wiad Lek. 2019;72(3):462-465.

4. P Boffano, F. Roccia, E. Zavatteroet et. al. European Maxillofacial Trauma (EURMAT) project: A multicentre and prospective study . J. Craniomaxillofac. Surg. 2015;43(1):62-70.

5. Murray J. M. Mandible fractures and dental trauma. Emerg. Med. Clin. North. Am. 2013;31(2):553-573.

6. R. Gutta, K. Tracy, C. Johnson et. al. Outcomes of mandible fracture treatment at an academic tertiary hospital: a 5-year analysis. J. Oral. Maxillofac Surg. 2014;72(3):550-558.
7. M. Motamedi, E. Dadgar, A. Ebrahimi, et al. Pattern of maxillofacial fractures: A 5-year analysis of 8,818 patients. J. Trauma Acute Care Surg. 2014;77(4):630-634.

8. Maladiere E., Chikhani L., Meningaud J.P. Osteosynthese des fractures sous- condyliennes par vissage en compression selon la technique $\mathrm{d}^{\prime}$ Eckelt. Experience etdifficults de la technique sur 5 ans. Rev. Stomatol. chir. Maxillofac. 1999;100(2):75-81.

9. Gola R., Chossegros C., Cheynet F. Current surgical approach to masticatory system pain-dysfunction syndrome (SADAM) Rev. Stomatol. Chir. Maxillofac. 1994;95(3):241-254.

10. Scully C. Oral and Maxillofacial Medicine. The Basis of Diagnosis and Treatment. Edinburgh: Elsevier, 2008.

11. Wilkes C.H. International Derangement of the Temporomandibular Joint. J. Otolaringol. Head Neck Surg. 1989; 115:469-477.

12. Petrosov Yu.A., Kalpakyants O.Yu., Seferyan N.Yu. Diseases of the temporomandibular joint. Krasnodar: Soviet Kuban, 2009, p. 352.

13. LeResche L. Epidemiology of temporomandibular disorders: implications for the investigation of etiologic factors. Crit. Rev. Oral. Biol. Med. 2014; 8:291-305.

14. Smahlyuk L.V., Trofymenko M.V. The structure of symptoms of temporomandibularjoint dysfunction depending on the morphofunctional status of the dentofacial area. Dentistry Journal. 20015; 2(47):75-77.

15. Dworkin S.F., LeResche L., Craniomand J. Research diagnostic criteria for temporomandibular disorders: review, criteria, examinations and specifications, critique. Disord. 1992; 6:301-355.

16. John M.T., Hirsch C., Reiber T. et al. Translator the research diagnostic criteria for temporomandibular disorders into German: evaluation of content and process. J. Orofac. Pain. 2006; 20:43-52.

17. Lobbezoo F., van Selms M.K., John M.T. et al. Use of the research diagnostic criteria for temporomandibular disorder: for multinational research: translation efforts and reliability assessments in The Netherlands. J. Orofac. Pain. 2005; 19: 301-308.

18. Helkimo M. Studies on function and dysfunction of the masticatory system. II. Index for anacrotic and clinical dysfunction and occlusal surface. Swet. Dent. J. 1994; 67:101-121. 
19. Salvetti G., Manfredini D., Bazzichi L. et al. Clinical features of the stomatognathic involvement in fibromyalgia syndrome: a comparison with temporomandibular disorders patients. J. Craniomandibular Pract. 2007; 25: 127-133.

The work is a fragment of scientific research work of the Department of Surgical Dentistry and Maxillofacial Surgery of the Higher State Education al Institution of Ukraine "Bukovinian State Medical University" "Multidisciplinary approach to the diagnosis, treatment and prevention of major dental diseases, with the preservation of regenerative properties of tissues and the restoration of the protective properties of anatomical structures in residents of Northern Bukovina." (state registration number 0116U002929).

\section{ORCID and contributionship:}

Olga L. Skrypa - 0000-0003-2823-1719 A,B,C,D

Yurii L. Bandrivsky - 0000-0002-4103-3664 ${ }^{E, F}$

\section{Conflict of interest:}

The Authors declare no conflict of interest:

\section{CORRESPONDING AUTHOR}

Olga L. Skrypa

Higher State Education al Institution of Ukraine

"Bukovinian State Medical University"

Kopernika street 6/7458000, Chernivtsi, Ukraine

tel: +380503737557

e-mail:bandrivsky.83@gmail.com

Received: 14.05 .2019

Accepted: 27.12.2019

A - Work concept and design, B - Data collection and analysis, C - Responsibility for statistical analysis,

D - Writing the article, $\mathbf{E}$ - Critical review, $\mathbf{F}$ - Final approval of the article 